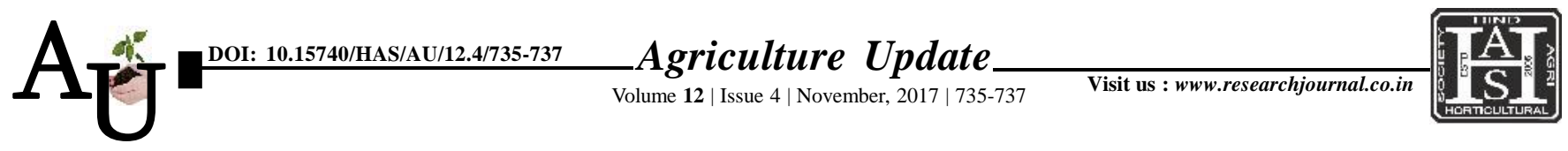

口 e ISSN-0976-6847

\title{
Research Note: Development and standardization of attitude scale of women towards kitchen gardening
}

H. SAINI AND N.B. CHAUHAN

Article Chronicle : Received :

10.01.2017;

Accepted :

30.10.2017

KeY Words :

Attitude, Kitchen

gardening, Scale

product method

Author for correspondence :

\section{H. SAINI}

Department of

Extension Education,

B.A. College of

Agriculture, Anand

Agricultural University,

ANAND (GUJARAT) INDIA

Email:hlatahem@

gmail.com

See end of the article for

authors' affiliations
SUMMARY : The study was conducted to develop and standardize the reliable and valid scale, to measure attitude of women towards kitchen gardening. Appropriate statistical methods 'scale product method' was used, which combines Thurston and Likert techniques. Twenty one statements were selected for judgment; a panel of 50 judges was requested to assign the score for each statement on five point continuum. Based on the scale (median) and Q values, eleven statements were finally selected to constitute attitude of women towards kitchen gardening.

How to cite this article : Saini, H. and Chauhan, N.B. (2017). Development and standardization of attitude scale of women towards kitchen gardening. Agric. Update, 12(4): 735-737; DOI : 10.15740/HAS/AU/12.4/735-737. 